Hans Rindisbacher

Pomona College, USA

\title{
THE LINGUSTIC AND CULTURAL MANIFESTATIONS OF WAR AND TERRORISM
}

\section{What the soldiers say: Swiss Army jargon and its links to civilian life}

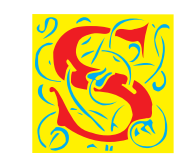

witzerland in the past, before the end of the Cold War at least, liked to think of itself as a nation in terms of a Sonderfall, an exceptional case. This Sonderfall thinking applies to their role in the middle of Europe but outside the EU, to their federal political system of radical bottom-up democracy and far-reaching decentralization of power, their multilingualism, perhaps multiculturalism, and their increasingly rare militia army system - beside many other things such as the peaceful coexistence of Catholicism and Protestantism, the widespread use of dialect in oral and standard language in official media communication, etc., etc. Despite this self-ascribed status, they also liked to think of themselves as a potential model for a diverse Europe of many distinct but peacefully coexisting smaller political units.

Given our workshop title, the Swiss case is a kind of counterpoint: It is about an army that has not fought a war in a long time in a country that has not (yet?) been affected by global terrorism. Language in the military, the sociolinguistics of the army and its peculiarities thus offer just such an example of the many areas of cultural and political life, where the Swiss like to think of themselves as different.

However, before turning to the socio-linguistic dimension proper of my project and presenting a few concrete examples of Swiss soldiers' language, I need to turn to some socio-linguistic aspects first and provide bit of context that is historical, sociological, political, and broadly cultural. 
Bear in mind the following: ${ }^{1}$

- Switzerland is a neutral country. (Neutrality and its various interpretations over time is a fascinating topic in its own right but cannot be addressed here).

- Swiss army has never fought a war in the modern age. It was mobilized during the Franco-Prussian war 1870-71 (where, in the country's north-western border parts of the French forces under General Bourbaki, pushed by the Germans, were taken in and disarmed, according to the neutrality principles); ${ }^{2}$ it was mobilized again during WW1 and WW2, but did not fight.

- Swiss army is a strictly defensive military instrument; it cannot be deployed abroad. However, since the early fifties, Swiss army personnel do participate in international peace keeping and observer missions. ${ }^{3}$

- Swiss army is a militia army with general male draft. In the age when most European countries have moved to a volunteer professional military, this has become an exception. But the Swiss are clear about it: they reconfirmed this model in a vote in 2013 , that was triggered by an initiative. ${ }^{4}$

- Switzerland breaks up its total service time (which amounts to a life-time service of ca. 260 days for regular soldiers) into smaller blocks, beginning with a ca. 4-month-long boot camp/basic training and shorter (3 weeks) "refresher courses."

- The army is deeply historically rooted in the population due to centuries-old mercenary service, its militia character, its cantonal organization, its

1 Several Wikipedia and other Websites provide a good general overview and basic information on the Swiss military system: on military history and general issues, see https:// en.wikipedia.org/wiki/Military_of_Switzerland; on conscription: https://en.wikipedia.org/ wiki/Conscription_in_Switzerland; on military service in general: http://www.vtg.admin. ch/internet/vtg/de/home/militaerdienst/rekrut/wehrpflicht.html.

2 Wikipedia provides a, for the purpose of this paper sufficiently detailed, account of this incident: https://en.wikipedia.org/wiki/Charles-Denis_Bourbaki. As a first example of the linguistic creativity and metaphorical transfer of meanings and allusions, to this day, Swiss soldiers well call each other, tired after a long march or exhausted by field exercises and looking the part, "a Bourbaki," in analogy of the desperate conditions the French army unit found itself in in 1871.

3 SWISSINT is the coordination center of all international peace promoting deployments in peace promoting missions, civilian, military and otherwise. For a brief history of international deployments of Swiss army units since 1953, see http://www.vtg.admin.ch/ internet/vtg/en/home/themen/einsaetze/peace.html

4 Austria held a similar, though non-binding, referendum in January 2013 and the population also rejected the move from conscription to a professional army. 
distribution into the home of each serviceman of key personal equipment, and the organization of service-readiness via extra-service shooting practice.

- In late-medieval and early modern times Swiss mercenary troops served all over Europe, and foreign military service was an important factor of the economy of the cantons that only later (1848) fully organized themselves into the confederation that is modern Switzerland.

- The Swiss military's roots also extend to folklore, notably through the common practice of target shooting and shooting festivals. Even today, soldiers are required, as part of their service obligation, to target shoot annually and achieve a minimum number of points.

- Switzerland is a multilingual country, with the German-speakers (the majority, ca. $2 / 3$ of the population) speaking various, although mutually largely comprehensible dialects. However, these dialects deviate significantly from standard high German - which dominates the written form of communication, including significant sectors of the electronic media. The country's unique multilingualism and dialect/standard diglossia is reflected in the language usages of the army.

- The other national languages beside German are French (ca.1/4 of the population), Italian (ca. 8\%) and a few Romansh speakers (ca. 0.5\%); the population segment that lists "other languages" as their mother tongue has been growing steadily and stands now at ca. $20 \%$ of the population. Those who serve in the army generally speak one of the national languages. However, many among this group are non-citizens and, hence, do not serve.

More peculiarities could be added - governmental, historical, cultural, and educational - and all have some consequences for our topic at hand, Swiss military jargon.

The first such consequence is, and this may come as a disappointment for my listeners, there is not much of a distinct Swiss military language! I'll point out the reasons in detail shortly. Nevertheless, there are interesting sociolinguistic facts and details to be explained. In doing so, I will largely concentrate on and present examples from German. Having to point out this limitation only highlights the obvious that the Swiss army includes troops from various language regions. Indeed, the question of linguistic integration and the army's role in Switzerland's multilingualism have recently gained in importance. More on this below.

But even for German alone, the situation is not straightforward, because the reality of daily life - and, hence also life in the armed forces - is one of di- 
glossia: The (German-speaking) Swiss read, write, and consume media largely in standard high German, but in their daily lives speak almost exclusively their significantly diverging regional dialects. ${ }^{5}$

How then does the army deal with the country's official quadrilingualism? - Historically, army units have been recruited regionally in order to keep them largely monolingual and hence easier to manage. This has always been an approximation rather than full reality (for sheer numerical and structural reasons). Units from one language area might serve their refresher courses in a different language region (my own example is of a Bernese artillery battery serving in French-speaking canton Vaud, where there is a base for artillery training). But more recently, in the post Cold-War present of the past 25 years, the size of the army has been cut and simultaneously the need for all sorts of special-skills units has grown, notably in dealing with electronic equipment for communication, fire control, etc. The Swiss, always aiming to make the best use of their militia system, heavily rely on knowledge transfer from civilian to military life and recruit and place men accordingly. The smaller numbers and increased need for specific skills, broadly speaking, is leading to more linguistically mixed groups (see the work of Georges Lüdi, below).

Interestingly, this increased need for collaboration among soldiers of different mother tongues is not resulting, as one might surmise, in everybody switching to English; this is only one of the translingual practices the men draw on in real-life interaction.

I need to step back for some context: that English might become the default national lingua franca has become a significant cultural concern far beyond the army as immigration in recent years has broadened the spectrum and increased the number of speakers of languages beyond the official four. Moreover, language teaching in the Swiss school system, for better or for worse highly federalistically structured, with significant differences in approach in the cantons, has been under review and criticism for years - notably on the question of when (in what grade) to begin which foreign language in which language

5 The use of dialect has its historical ups and downs. Currently, dialect usage is on the rise, infiltrating above all private correspondence and spoken media (regional radio stations) but even certain television programming. This issue cannot be pursued here, but there is the obvious risk of a growing disconnect of German-speaking Switzerland from the larger German-language cultural area. The mores so as the ever wider-spread use of dialect also reflects a national unease in using High-German. Speakers of Swiss German dialects feel, as a rule, a bit of an inferiority complex when interacting with "real Germans," i.e., speakers of standard German in oral communication. 
region of the country! The Swiss national science foundation (Nationalfond) sponsored a long-term research project ("Sprachvielfalt und Sprachkompetenz in der Schweiz" (NFP 56 $6^{6}$, which also includes research on language usage in the army. ${ }^{7}$ While in civilian life, the use of English in translingual Swiss communication has in fact increased, in the army, this has been less the case, as a forthcoming study by Georges Lüdi reveals. ${ }^{8}$ Some of his key findings are:

First and surprisingly, there is no language policy in the Swiss army.

Second, given this absence, translingual interaction occurs ad hoc and reflects the linguistic competencies of those involved. Under the circumstances,

German is clearly favoured by the implicit language regime. The proportion of German-, French- and Italian-speaking members of the Armed Forces corresponds roughly to that in the general population (with a slight dominance of German among the officers), however, in relation to total investments of several billion francs as reported in the media, there is very little investment in language education for members of the army, except for English for professional officers. The system relies in general on skills acquired in civilian life. As we have seen, these are good or even excellent among staff members, but very divergent and sometimes quite poor in the case of recruits and instructors in basic training camps. Despite running central translation services for some official documents and technical regulations, the army does not provide for professional translation and interpretation in the daily military routine, but relies on plurilingual peers. German dominates as exemplified by the monolingual documentation for the staff exercise. The actors make use of an impressive number of communicative strategies, including lingua receptiva, plurilanguaging, English as lingua franca and interpretation by peers (in the

${ }^{6}$ A list of scholarly publications on the sub-project investigating plurilingualism in the army, titled "Wissenschaftliche Publikationen im Rahmen des Projekts 'Wie funktioniert Mehrsprachigkeit beim Militär?"' is attached to this paper.

7 The Schweizerischer Nationalfonds quarterly publication, Horizonte summarizes briefly the critical results of multilingualism in the army. Horizonte 81, June 2009, 22. The project was directed by Bernhard Altermatt, Monika Heiniger, Georges Lüdi, and Georg Kreis.

${ }^{8}$ As one of the SNF researchers, Georges Lüdi, Prof. emeritus in linguistics and French at the University of Basel, has been working on a study on the sociolinguistic dimension of language use in mixed-language contexts in the army (forthcoming). One of the chapters is focused on "Language regime in the Swiss Armed Forces between institutional multilingualism, the dominance of German, English and situated plurilanguaging." Lüdi was generous enough to send me a draft version of the chapter (e-mail to the author). Lüdi, in turn, references extensively the study by Raphael Berthele and Gabriele Wittlin, "Receptive Multilingualism in the Swiss Army," International Journal of Multilingualism, 102 (2013): 181-95. https://doc.rero.ch/record/208826? ln=de 
basic training camps as well as in the staff exercise), mostly successfully; however the minorisation of French, and in particular of Italian, is noticeable. ${ }^{9}$

Thus Lüdi's study (building on others, e.g., Berthele, Wittlin, et al.) reveals that communication in the army between the four national languages is pragmatic, contextual, dependent on the language abilities of the people involved, and mostly succeeds on the key role played by multilingual individuals. English does play a role, but it tends to be minor. German, according to Lüdi's findings, is dominant, as one might expect, given the population numbers, and this does have a minorization/alienation effect on French and Italian speakers. Moreover, these findings raise the question of levels of education and second- or third-language knowledge in the army and with it the question of parallelism between military rank and civilian class/economic position in connection with the militia system. I will address this question later.

The situation in the army begs the question as to the country as a whole. The current Swiss constitution (promulgated Jan. 1 2000) is benevolently vague. ${ }^{10}$ Article 4 states "The National Languages are German, French, Italian, and Romansh." Article 70 reiterates that "[ $[\mathrm{t}]$ he official languages of the Confederation are German, French and Italian. Romansh is also an official language of the Confederation when communicating with persons who speak Romansh.” It further notes "The Cantons shall decide on their official languages" and "The Confederation and the Cantons shall encourage understanding and exchange between the linguistic communities." Moreover, "the Confederation shall support the plurilingual Cantons in the fulfillment of their special duties," and "The Confederation shall support measures by the Cantons of Graubünden and Ticino to preserve and promote the Romansh and the Italian languages." The Federal Chancellery, i.e., the administrative arm of the federal government in Bern, emphasizes on its Website the fact of Swiss multilingualism and outlines its position, which is supportive of multilingualism. ${ }^{11}$ Nevertheless, public anxiety about an ever growing use of

\footnotetext{
9 Excerpt from Lüdi's forthcoming publication.

10 Online at https://www.admin.ch/opc/en/classified-compilation/19995395/ 201506140000/101.pdf

11 https:/www.bk.admin.ch/themen/lang/04925/04939/index.html?lang=de, unavailable in English. "Sprachenfragen nehmen in der schweizerischen Politik und im schweizerischen Recht viel Raum ein, wobei traditionellerweise die Landes- und Amtssprachen im Vordergrund stehen. Die Landessprachen der Schweiz sind nach Artikel 4 der Bundesverfassung Deutsch, Französisch, Italienisch und Rätoromanisch. Die Förderung dieser Viersprachigkeit ist ein zentraler Grundsatz der schweizerischen Sprachenpolitik.”
} 
English in the military has recently triggered parliamentary inquiries, information requests in parliament that the executive has to answer.

Thus MP (Nationalrätin) Ms Kiener noted on March 15, 2009 the growing role of English, pointed out that previously the army was a model of multilingualism, and asked the executive how they assess the situation and whether the federal government was willing to again support the use of national languages and suppress English. ${ }^{12}$ The answer is that the national languages are still widely used and English restricted to international communication and that the government is limiting English as much as possible.

A similar inquiry from 2014 added an explicitly educational dimension and asked the Federal Council whether the army might not be used for foreign language education of a significant (male) segment of the population. In its reply, the government insists that the army is an integrative national institution, that it does promote multilingualism but that the teaching of national languages to soldiers from different language regions would detract from the main military-defensive purpose of army training, be too costly, and will therefore not be considered. ${ }^{13}$

A brief overview of purpose and main functions of the Chancellery itself, in English, is here, https://www.bk.admin.ch/index.html?lang=en. It is the staff office of the Federal Council, i.e., the Swiss executive branch, and maintains, among many other duties, official Swiss government websites.

12 Inquiry: "Immer mehr werden die Ausbildung und der Dienst in der Schweizer Armee dominiert durch den Gebrauch englischer Bezeichnungen und Ausdrücke. Früher war die Armee vorbildlich in der Pflege unserer Landessprachen.

- Wie beurteilt der Bundesrat diese Entwicklung?

- Ist der Bundesrat bereit, die Pflege unserer Landessprachen auch in der Schweizer Armee hochzuhalten und den Gebrauch der englischen Sprache zu minimieren?"

Reply: "Die Landessprachen der Schweiz werden in der Armee gleichberechtigt gepflegt und angewendet. Der militärische Alltag ist nach wie vor, sowohl in der Ausbildung wie auch im Dienstbetrieb, durch die klassischen Landessprachen geprägt. Die Kommunikation erfolgt in der Regel in der jeweiligen Muttersprache. Englische Begriffe werden dort verwendet, wo es die Zusammenarbeit mit dem Ausland im Rahmen von Einsätzen oder der Ausbildung notwendig macht. Der Bundesrat ist bereit, den Gebrauch der englischen Sprache in der Armee auf das absolute Minimum zu reduzieren.” Die Bundesversammlung - Das Schweizer Parlament. Fragestunde. https://www.parlament.ch/de/ratsbetrieb/ suche-curia-vista/geschaeft?AffairId=20095123

13 Interpellation by Didier Berberat, 24 Nov 2014, in the Council of States. The inquiry, together with the federal government reply, can be found here: Die Bundesversammlung - Das Schweizer Parlament. Fragestunde. https://www.parlament.ch/de/ratsbetrieb/ suche-curia-vista/geschaeft?AffairId=20144020 
For context I should add that both these inquiries tap into an ongoing broad national debate about Switzerland's multilingualism, how to preserve it, how to approach it in schools and, notably, when to begin English language instruction and whether to privilege it over national languages.

In light of this debate and the fact that there exists no official army-related language policy, what then does the actual language usage in the Swiss army look like? The answer to this question has two parts: the first relates to the official technical and command language of Switzerland's armed forces, the second to soldiers' private, unofficial informal communication. The first is of linguistic interest insofar as it routinely combines a mixture of Swiss dialects and standard high German. Apart from this, it is characterized by its high incidence of abbreviations and acronyms - a typical feature in professional jargon and socio-linguistically interesting only in that many of these abbreviations have a secondary, unofficial meaning that forms part of the second linguistic field discussed here, soldiers' private, non-official language.

The first dimension of army language is codified in a German-English dictionary. ${ }^{14}$ It is noteworthy that this dictionary uses in its German column strictly standard high German and thus reduces the existing diglossia, the de facto mixture of dialect and standard, from the outset. Command of a language is a mixture of standard and dialect expressions. While there are (unspoken) rules, switching from one to the other brings up the question of military rank: soldiers are held more strictly to receiving and repeating orders in standard German - officers can relax into dialect. Given the overall reluctance of Swiss speakers of German to use standard high German, however, there is a fine line to be observed in the length of utterances in high German to be expected from soldiers. Too long - and a repeated order may, by virtue of pronunciation and localisms, turn humorous instead of appropriately serious and snappy.

Of further note is the fact that there exists no monolingual glossary of Swiss official military language, as there is simply no practical need for it.

The second dimension of language in the military, the private individual communication among soldiers, is more linguistically interesting than the official technical. We noted at the outset that it varies little from everyday civilian language usage - with some notable exceptions to be discussed presently. But let's begin with the reasons for the large overlap between civilian and military

${ }^{14}$ Milvoc: Wörterbuch militärischer Begriffe (2014), comp. \& ed. VBS (Federal department of Defense, Civil Protection and Sport). This is a German-English and English-German dictionary/glossary of official, technical, and command military terms in two volumes. 
parlance or, to put it differently, the veritable absence of a distinct Swiss army language. These are predominantly structural.

First, service time overall is short, soldiers are not isolated from the rest of the population for long periods of time and therefore do not develop strongly divergent linguistic practices. Additionally, this short service time is broken up into smaller pieces, reinforcing the seamless integration of military and civilian life. Second, the militia system intensifies civilian-military integration also in the ongoing part-time commitment to military tasks by officers in their civilian jobs (communication, preparation for the next service period, meetings, etc.). Doing such army-service related prep work also implies the characteristic diglossia: one would put something in writing in standard German but make a phone call in dialect, for instance.

The notable distinction between civilian and (private) army language is largely a question of specific lexicon and register, mostly the latter. ${ }^{15}$ Soldiers, men out there among other men in the woods and barracks, generally lower their standards of civilian conversational expectations and civility. Certain lexical fields gain prominence. Horst Schuh notes that the largest lexical fields are food, drink, sex, excrement/defecating. ${ }^{16}$ Soldiers, he writes, talk "more about shitting than shooting." Soldiers' lexicon is characterized by abundant metaphor, and this is where its linguistic creativity resides - besides the innovative alternative meanings assigned to official abbreviations - frequently with social,

15 Several Internet sites provide glossaries of soldiers' language: http://www.wk.devanthey.ch/Lexikon.html. This is a private person's website with a compilation of Swiss German military language. The original terms have been largely standardized from their dialectal forms, though.

https://de.wiktionary.org/wiki/Verzeichnis:Deutsch/Soldatensprache_der_Schweizer_Armee - This is probably the most comprehensive compilation of army slang, more comprehensive than Devanthey's.

http://www.armee-forum.ch/archive/index.php/t-205.html. This is another private compilation of contemporary soldier's terminology, linked to an army-related blog, armeeforum.ch.

https://www.infbat70.ch/index.php/17-highlights/21-soldatensprache. This is a compilation of terms on an Infantry Battalion's website, largely identical with the wiktionary site, above. A note on the page acknowledges the link: "Die folgende Aufstellung haben wir in der deutschsprachigen Wikipedia gefunden und leicht angepasst."

http://www.snf.ch/de/fokusForschung/forschungsmagazin-horizonte/archiv/Seiten/default.aspx. This Swiss National Science Foundation link (Nationalfonds, Horizonte, June 2009) provides a brief project overview of the Army language research.

16 H. Schuh, "Sprache und Moral," in: Heere International 3, hrsg. v. H.-A. Jacobsen and H.-G. Lemm, Herford \& Bonn: Verlag Mittler \& Sohn, 1984, 64-73, here 69. 
sexual or other subversive innuendos.

Here are a few harmless examples to start with: the old and odd-looking all-terrain vehicle to pull howitzers, the Swiss-made Saurer $4 \mathrm{MH}$, was called "Heckferrari"; a more recent Jeep-like all-terrain vehicle by the Austrian manufacturer Steyr-Puch was called "Österreichische Strassensperre," an "Austrian road-block," on account of the fact that it is vastly underpowered. The earliest jet fighter in the Swiss air force, the British deHavilland Venom, that the Swiss, taking good care as they do of almost everything, kept flying far beyond its useful lifetime, was labeled a "Düsenvelo," a "jet-bike," literally, the term thus combining the jet-age aspiration with the simplicity and slowness of a bicycle - analogous in intent to the "Heckferrari." We see here that the neutral technical terms/names are replaced by more colorful, descriptive, often ironic or satirical monikers.

(Fake) acronyms and abbreviations add their own color, such as: SABTAL - "sicheres Auftreten bei totaler Ahnungslosigkeit." It translates as "self-assured appearance while being without a clue" and is a leadership principle that soldiers may diagnose in a superior who appears and acts brashly and self-confident when in fact he is an ignoramus. A "Selbstzünder," literally a "self-detonator," is the term for a superior, usually of lower rank, such as a corporal, who is full of good intentions and highly active - but with little goal orientation or much to show for it. The positive English term would be a "self-starter." Another short is "hä-si-be," the abbreviation for a reply to the question what one's current assignment is. It stands for "hält sich bereit," "holds himself ready/available" - when one has in fact nothing to do, is without assignment, and just hanging out. It is used humorously among soldiers, not in soldier-superior interaction.

Kitchen and food, eating, and digesting, according to Schuh, is a prolific lexical field and largely free from the political correctness of our day. Indeed, rice is called "Chinesebeton," "Chinese concrete"; coffee or cocoa was (at least in my days) termed "Negerschweiß," i.e., "negro's sweat," while the individual bars of dark army chocolate go crudely as "Arschlochbarriere," an "asshole barrier," for their constipating effect. Further examples could be listed of course: colorful, highly descriptive, racist, politically incorrect, and therefore mildly subversive. The "Grabstein," (gravestone) for the American "dog tag," is metaphorically just as accurate but draws its tertium comparationis from a different lexical field and realm of the imagination; and "Toblerone," for the double rows of huge triangular concrete blocks set into the landscape to prevent enemy tanks from entering a piece of particular geography during WW2 and still existing in 
some places, is a visually creative analogy that also makes the object less formidable than it was once meant to be.

The most notorious examples of Swiss soldiers' jargon, revealing the country's remove from the horrors of twentieth-century history, are two terms that show an utterly politically insensitive Swiss military. Until recently, the sick room in barracks, the doctor's office, was still called the "KZ," for "Krankenzimmer," "sick room)," despite its notorious other meaning the acronym has across the globe. And the hapless puck of canned meat that often was part of MRE's was notoriously and offensively called "gschtampfte Jud," "mashed Jew." In 2010, the Swiss Military Library answered an inquiry regarding the origins and use of this term. As so often in (historical) sociolinguistics, the answer is not clear, but the notion that the term existed even before WW2 seems implausible. ${ }^{17}$

Given that the Swiss army as all male there is a tone among soldiers (less among officers, though) - notably when talking about women and, consequently, sex - that one does not find in gender-mixed company. Max Frisch, the well-known $20^{\text {th }}$-century Swiss writer who served considerable time in the military during WW2, wrote about his experience in two short books, bringing to bear a fine, critical, and notably socially aware point of view. He comments on this phenomenon, emphasizing that particularly around gender discrimination, sexism, and female objectification there existed rather firm lines between civilian and military realms and soldiers stuck to them.

In the hay, after lights-out when one was not supposed to talk anymore, or in a warehouse, where one was allowed to talk, or on watch, during the day, out in the field, during work, in the cafeteria or sitting on boxes, while cleaning and greasing howitzer parts - barely anyone ever mentioned their civilian work. The quintessence of civilian life was the dick. Not everyone was good at dirty jokes, but most of them were happy listeners. If one later met one or the other on furlough with his wife or bride, they were arm in arm. The revolt that drives every dirty joke never referred to one's wife. A place where one never heard dirty jokes: under the shower, stark naked in the steam. ${ }^{18}(70-71)$

17 The contextualized and somewhat sanitized answer is online; the letter of inquiry to the library was from Daniel Suter; the librarian answering Juri Jaquemet (March 4, 2010). http://www.alexandria.ch/primo_library/libweb/action/search.do?formResourceIdentifier=form_copy\&_charset_=UTF-8\&vl\%28freeText0\%29=gestampfter+Jude\&vid=ALEX\&ct=facet \&ct=BasicSearch \&fn=search

${ }_{18}$ M. Frisch, Dienstbüchlein, Frankfurt/M.: Suhrkamp, 1974. 
As some of the expressions above relate to old things such as trucks and airplanes that have long been replaced, the question arises as to the historicity or at least the longevity of (Swiss) soldiers' jargon and, somewhat related to this, about the origin of sociolinguistic interest and beginning research into this field in the first place. Schuh notes that research into military jargon began in earnest around 1900 , triggered by emerging social and linguistic interest in group languages and (professional) jargon at the time. For the Swiss army, the fact that Bächtold's work starts around WW1 confirms this. Bächtold, notably his glossary, is still referenced today. This is testimony to its value but also to the fact that there have been long periods when army language did not receive much scholarly attention despite consistent high-quality output in dialectology, Volkskunde (ethnology) and, from the 60 's onwards, in sociolinguistics and pragmatics. Around WW2, the political satirical weekly Nebelspalter occasionally published a page on soldiers' talk and military life, often accompanied by anecdotes; and in the late 1970's two small book-length collections of Swiss army jokes, anecdotes, and stories appeared, involving both dialect and high German. ${ }^{19}$ Their author, Fritz Herdi, also worked for the Nebelspalter. The most recent academic effort is the National Research Foundation project already mentioned, the "Nationale Forschungsprogramm zur Mehrsprachigkeit der Schweizer Armee." ${ }^{20}$ But overall, notably in the Swiss context, this kind of research is a small field with plenty of cross-referencing. For years, there were few research papers or, more frequently, general comment or sampling of terms, often with humorous intent, on the army and its language. Only recently and in the broader socio-linguistic research contexts of the recent national research project or language education in schools have language issues in the army gained more attention. In conclusion, we have to acknowledge that the situation is in flux as the ongoing army reorganization and reduction reshapes some older parameters. The changes point toward the further leveling of the civilian-military distinction in language usage in Switzerland. The introduction, long in coming, of a civil ser-

19 F. Herdi, Heiteres aus feldgrauem Dienst, Hrsg. v. ASZM, Allgemeine Schweizerische Militärzeitschrift, Frauenfeld: Huber, 1985. This book-length collection of anecdotes, explanations and commentary is followed by a traditional alphabetical list/index of the terms referenced, whereby the standard German notation provides the alphabetical order, the dialectal equivalents, generally more than one, are the referents.

${ }^{20}$ Briefly outlined on the SNF's website, http://www.snf.ch/de/fokusForschung/forschungsmagazin-horizonte/archiv/Seiten/default.aspx, Horizonte, June 2009, 22. The Forum Helveticum, an umbrella organization of many public political, academic and civic institutions also briefly discusses the topic of military language http://www.forum-helveticum.ch/logicio/pmws/forumhelveticum__armee_de.html 
vice option in 1996, had already fractured the demographic serving in the army. ${ }^{21}$ Additionally, the reduced numbers of servicemen, together with the trend toward higher technical specialization, goes against the older trend of forming monolingual units in favor of translingual special-knowledge work teams. These trends are probably not outweighed by the now available "Durchdiener" option, i.e., the option to serve one's military service all in one stretch - which, on the face of it, might lead to the development of a more pronounced military jargon.

To some extent, Frisch's observations from the 1970's still hold some sway that the army higher-ups are also the economic higher-ups and leading figures in Swiss civilian and political life. He notes that men who do not get together socially also realize quickly - and the army strengthens this conviction - that they do not mix well in the ranks. The higher ups stay the higher ups - partly for reasons of their "natural" authority, i.e., the authority they practice in civilian life. The assumption and natural acceptance among the troops that their leaders are also "their betters" is, at least implicitly, not uncommon. This leads to a reflexive, largely unquestioned transfer of authority from civilian to military life. (Dienstbüchlein, 34-35). Frisch at one point goes so far to call the officers a "caste" (Dienstbüchlein, 54) that keeps separate from the troops - and vice versa. Language use, especially switching of register, reflects and confirms this claim.

The Swiss army, not last when discussed from the angle of its language, is thus a good example of the concept of "citizens in uniform." The men get together in "old boys" cohorts, use the technical vocabulary as necessary and lower their civilian conversation standards a little, notably in gender terms, for the duration of their service. But once back in civilian life and in mixed-gender company, they quickly regain their general decency. This ability to switch from one mode and one code to the other seems almost second nature, a reflection of the militia system, the short service times, the integration of civilian and military life as well as an effect of the small size of the country that allows only minimal separation of military and civilian spaces. Especially for the older cohorts, the annual refresher courses become a form of camping: you rough it for three weeks and then return to everyday life - to your job, your friends, and your language.

${ }^{21}$ Legally, the EMRK, to which Switzerland signed on in 1974, may not constitute a requirement for a civil service option, but contemporary legal interpretation and practice strongly suggests it should. 